\title{
Slavonic Translation of the Apocryphal Questions of Bartholomew
}

\author{
Martina Chromá
}

Institute of Slavonic Studies, Czech Academy of Sciences

chroma@slu.cas.cz

\begin{abstract}
The paper deals with the Slavonic translation of the apocryphal Questions of Bartholomew, a literary text written most likely in Greek in the 3rd or 4th century.
\end{abstract}

\section{Keywords}

Questions of Bartholomew - Old Church Slavonic - apocrypha

Apocryphal Questions of Bartholomew (BHG 228) is a Greek literary text written most likely in the $3^{\text {rd }}$ or 4 th century ${ }^{1}$ and later translated into Latin and Old Church Slavonic. The text survives in three known Greek, two Latin and six Slavonic manuscripts. Although there have been published some studies summarizing the Greek and Latin versions of the apocryphon already, ${ }^{2}$ not much attention has been paid to the Slavonic translation so far.

The text of the Questions of Bartholomew (further abbreviated as Bart) is structured in the form of questions and answers. The plot is divided into five

* The present paper was written with the support of the grant GA ČR P406/12/179o Staroslověnská lexikologie - nové prŕspěvky ke staroslověnské lexikografii.

1 According to some of the newest researches, the apocrypha could not have been written earlier than in the 4th century, see C. Markschies, "Die Fragen des Bartholomäus," in: Antike Christliche Apokryphen in deutscher Übersetzung 1/1, eds. C. Markschies and J. Schröter, Tübingen, 2012, p. 709.

2 For example J.-D. Kaestli and P. Cherix, L'Évangile de Barthélemy, d'après deux écrits apocryphes, Turnhout: Brepols, 1993, or Markschies, "Die Fragen des Bartholomäus," pp. 702-850. 
chapters of variable length: ${ }^{3} 1$ ) apostles ask questions to Christ about his descent into Hades and the release of captured Adam and the patriarchs; 2) Virgin Mary tells apostles about the events that preceded the Incarnation of Christ; 3) apostles beg Christ to show them the apocalyptic abyss; 4) apostles beg Christ to show them the human adversary and after he does so, they ask questions to Satan about his persona, angels and about his guilt which led to his fall from heaven (Slavonic manuscripts contain only verses 1-13 of this chapter - they end with the description of the chained Satan); 5) apostles ask questions to Christ about the greatest sin and marriage. Some parts of this last chapter are supposed to be later additions to the original text as they are preserved only in one Latin manuscript.

Bart is a typical New Testament apocryphon written in a simple and lucid style. Although a number of biblical quotations is mentioned through the whole text, some heretical elements typical for the Monophysitism or Docetism can also be found there. There is a question whether those elements had been understood as heretical even in the Slavonic environment in the Middle Ages. It is known that some heresies (e.g. the Bogomilism and Paulicianism) occurred in the Slavonic South quite early after the official Christianization, but the situation there seems to be different than the one of the Byzantine Empire which had the greatest influence on the Balkan church. While the Byzantine church administration and hierarchy had been already formed and its dogmatics was being examined by a series of church councils, the Slavonic church of that time was just starting to develop. The main task of the Bulgarian emperors was dealing with the persisting Paganism of the population whilst the purity of the Christian doctrine had a secondary role. ${ }^{4}$ For this reason, it is assumed that the apocryphal texts weren't understood categorically as heretic or false as the priority was the spread of stories linked to the Christian religion. As shown below, the later purifying of the texts touched even the Slavonic translation of Bart. Although the genre of the apocryphal literature was very popular in the Slavonic environment, we don't know much of the purposes for which those texts should have served, especially if they were intended for private or non-private readings or for some kind of monk's education in the monasteries or for other purpose.

We are aware of three Greek manuscripts containing the text of the analysed apocryphon. The first one is held in the Austrian National Library in

3 This division into five chapters and verses was first made by Nathanael Bonwetsch in his edition of the Greek Viennese ms (see below) and since then it is usually used in the literature on the apocrypha.

4 M. Loos, Dualist Heresy in the Middle Ages, Prague, 1974, p. 42. 
Vienna (Cod. Hist. Graec. 67) and it is dated to the 13th century. Unfortunately, the majority of the first chapter is missing - the text contains only the verses 1:28-5:10. ${ }^{5}$ The text is divided into two parts (verses 4:54-5:11 and 1:28-4:53) mingled with similarly splitted text of the Life of Adam and Eve most likely due to incorrect binding of the folios. The second Greek MS is held in the library of the Greek Orthodox Patriarchate in Jerusalem (Cod. Hierosolymitanus Sabbaticus 13). The whole codex is dated to the turn of the 1oth/11th century, but the text of the Questions of Bartholomew was added on the blank folios just in the 13th century. ${ }^{6}$ Verses 1:1-4:32 of the apocryphon are preserved in this Ms, but the text is damaged on some places and it contains some omissions as well. The third Greek manuscript is dated to the $15^{\text {th }}$ century and it is held in Biblioteca Nazionale Marciana in Venice (Gr. XI, 24=1293). This manuscript has not been mentioned in the research of the apocryphon yet. According to the description of the codex in the French online catalogue of Greek manuscripts Pinakes, the text of the apocryphon contain some damages and errors. ${ }^{7}$ This Ms has not been included even into our research as we learned about its existence only recently.

The Latin translation of the Questions of Bartholomew is preserved in two manuscripts. The first one is dated to 11th century and it is held in the Biblioteca Casanatense in Rome (Bibl. Casanatense 1880). It contains the most complete text of the apocryphon (verses 1:1-5:11), but some of its parts (especially the fifth chapter) are supposed to be later additions. ${ }^{8}$ The second manuscript is held in the Vatican Library (Vat. Reg. Lat. 1050) and it is dated to the turn of the 9 th and 1oth centuries. It contains only few small fragments from the first and fourth chapter of the text. ${ }^{9}$

In the context of the state of the text preservation in the Greek and Latin manuscripts, it is necessary to underline the importance of the Slavonic ver-

5 The text of Bart by this manuscript has been published twice, see: A. Vasiliev, Anecdota graecobyzantina. Pars prior, Moscow, 1893, pp. 10-22, and N. Bonwetsch, "Die Apokryphen Fragen des Bartholomäus," Nachrichten von der Königl. Gesellschaft der Wissenschaften zu Göttingen. Philologisch-historische Klasse (1897), ss. 1-42.

6 A. Wilmart and E. Tisserant, "Fragments grecs et latins de l'Évangile de Barthelémy," Revue biblique, 10 (1913), p. 181. The only edition of the text of the apocrypha preserved in this manuscript was published in this article, see pp. 185-190, 321-333.

7 “Pinakes. Textes et manuscrits grecs," n.p. [cited 15 November 2016] Online: <http://pinakes. irht.cnrs.fr/notices/cote/7066o>.

8 The text has been published once, see: U. Moricca, "Un nuovo testo dell'Evangelo di Bartolomeo," Revue biblique, 30 (1921), pp. 481-516, and 31 (1922), pp. 20-30.

9 The edition of the fragments is included in Wilmart and Tisserant, "Fragments grecs et latins," pp. 176-18o. 
sion for the reconstruction of the original text of the apocryphon. This applies especially to the first chapter, from which the Viennese Greek manuscript is missing most of the verses and the Jerusalem Ms is partially damaged. Thus, only the Slavonic and Latin versions can be compared, even if they differ from each other in certain parts. There is a chance that the already mentioned Greek Venetian MS will shed some light on this problem, but this is a task for our future research.

There are six known manuscripts containing the Slavonic translation of Bart. Most of them have been described in the catalogue of Slavonic apocrypha of Aurelio de Santos Otero. ${ }^{10}$ Although three of these manuscripts have been published already, we've been working directly with all of the manuscripts during our research.

\begin{tabular}{|c|c|c|c|}
\hline Abbr. & MS mark and location & Origin and datation & Text included \\
\hline $\mathrm{D}$ & Deč. 103 (SNL Belgrade) & Serb., end of $14^{\text {th }} \mathrm{ct}$. & $1: 1-1: 23$ \\
\hline $\mathrm{P}$ & $\begin{array}{l}\text { Kir.-Bel. 4-1081 (RNL St. } \\
\text { Petersburg) }\end{array}$ & $\begin{array}{l}\text { Russ., beginning of } \\
\text { 15th ct. }\end{array}$ & $1: 1-4: 13$ \\
\hline $\mathrm{V}$ & $\begin{array}{l}\text { Cod. Vind. Slav. } 125 \text { (ÖNB } \\
\text { Vienna) }\end{array}$ & Serb., 16th ct. & $1: 1-4: 13$ \\
\hline $\mathrm{U}$ & Uvar. 884 (shm Moscow) & Russ., 1602 & $\begin{array}{l}\text { Excerpts from } \\
\text { chapters 1, } 3 \text { and } 4\end{array}$ \\
\hline B & Bars. $273^{\circ}$ (shm Moscow) & Russ., 17 th $/ 18$ th ct. & Chapter 1 \\
\hline $\mathrm{T}$ & $\begin{array}{l}\text { F. 1409. Op. 3. D. } 25 \text { (GATO } \\
\text { Tver') }\end{array}$ & Russ., 18 th ct. & Chapter 1 \\
\hline
\end{tabular}

The oldest manuscript was at the same time the last to be found as it was first described and published by Anissava Miltenova in $2010 .{ }^{11}$ It is held in the collection of the Dečani monastery of the Serbian National Library (Deč. 103) and it is dated to the end of the 14th century. Only a part of the first chapter of the text (verses 1:1-1:23) is preserved there, while the remaining parts of the manuscript are lost.

10 A. de Santos Otero, Handschriftliche Überlieferung der altslavischen Apokryphen, Bd. 2, Berlin - New York, 1981, ss. 56-59.

11 А. Милтенова, "За един неизвестен препис от апокрифните въпроси и отговори на апостол Вартоломей," in: Пяние мало Георгию: сборник в чест на 65-годишнината на проф. дфн Георги Попов, Sofia, 2010, pp. 464-477. 
The second oldest Slavonic MS is held in the collection of the Kirillo-Belozersky Monastery of the Russian National Library in Saint Petersburg (Kir-Bel 4-1081) and it is dated to the beginning of the 15th century. The codex is known under the name Paisievski sbornik and the text of the apocryphon has been published two times already. ${ }^{12}$

The next manuscript is held in the Austrian National Library in Vienna (Cod. Slav. 125) and it is dated to the 16th century. In this miscellany, the text of the apocryphon is split into two parts sequenced in different order than in the other manuscripts - it starts with chapters 2-4, after which the text of the John the Baptist's Descent into Hades is added, whilst the chapter 1 of Bart is placed just after this text. ${ }^{13}$ There is a presumption that this Serbian line of manuscripts came from the Russian environment as there are few Eastern-Slavic orthographical elements in the text.

The last three manuscripts haven't been published yet. One of them is from the Uvarov collection of the State Historical Museum in Moscow (Uvar. 884). It has been written in 1602 and it contains excerpts from the first, third and fourth chapter. The other two manuscripts contain only the first chapter of the apocryphon. The first one is held in the Barsov collection of the State Historical Museum in Moscow (Bars. 2730) and it is dated to the turn of the 17th and 18th century. The second one is located in the State Archive of the Tver Region in the city of Tver (F. 1409. Op. 3. D. 25). This manuscript is the youngest one as it is dated to the 18 th century. In comparison with the other Slavonic versions, this manuscript contains a number of later additions to the text.

Despite the fact that all Greek and Latin manuscripts originally included the whole text of the chapters 1-4, the Slavonic manuscripts show three different length types: the long one containing the text of the chapters 1:1-4:13, the abbreviated one with excerpts from chapters 1, 3 and 4, and the short one with only the chapter 1 included.

The long version can be found in the manuscripts $\mathrm{V}$ and $\mathrm{P}$. We suppose that MS D also represented the long version before some of its parts got lost, because the title of the apocryphon is similar the Mss V and P unlike the title with the specification of questioning Christ in manuscripts $\mathrm{B}$ and $\mathrm{T}$.

The abbreviated version with excerpts of the chapters 1,3 and 4 is preserved only in manuscript $U$. This abbreviation may be related to the style of the

А.Н. Пыпин, Ложные и отреченные книги русской старини (Памятники старинной русской литературы, 3), Saint Petersburg, 1862, pp. 109-112; Н.С. Тихонравов, Памятники отреченной русской литературы, vol. II, Moscow:, 1863, pp. 18-22.

13 В.Н. Мочульский, Следы народной библии в славянской и в древне-русской писменности, Odessa, 1893, pp. 276-281. 
whole codex, in which 65 different texts sequenced in accordance with the Eastern church calendar are placed. Taking into the cosideration the amount of the texts, the shortening of plots wouldn't be exceptional. Even though the feast of St. Bartholomew is celebrated on August 24 in the Western Church and on June 11 in the Eastern one, the apocryphon is placed behind the text of the Martyrdom of prince Gleb dated to July 24 to which St. Bartholomew doesn't have any connection.

The third version is the shortest one containing only the chapter one. It is preserved in MSs B and T. This shortening was probably made because of the special topic of the Christ's descent into Hades which has been in the Slavonic environment quite popular as it is shown e.g. in the Slavonic translations of the Gospel of Nicodeme ${ }^{14}$ or the Homily on the Descent into Hades by Epiphanius of Cyprus. ${ }^{15}$ The text shortening of the apocryphon in two different manuscripts may indicate the existence of a separate short redaction of the text. However, according to our research and comparison of the manuscripts we assume that the versions $\mathrm{B}$ and $\mathrm{T}$ were shortened independently as each one of them refers to another hyparchetype of the text (see below).

With exception of the already mentioned MS U, the Slavonic codices containing Bart are constructed as miscellanies of mixed content including unordered apocrypha, homilies, legends, etc. The similarities can be found just between the manuscripts $V$ and $B$ which are also the closest ones from the point of view of textual criticism. Both of these miscellanies include also the text of the shortest recension of the Second Book of Henoch and the John the Baptist's Descent into Hades which is placed next to Bart, apparently because of the topic's similarity.

The apocryphon has been translated into Old Church Slavonic only once which means that all extant manuscripts refer to just one unpreserved archetype. In comparison to the Greek version of the apocryphon, the translation is a literary one without using any extraordinary lexical, morphological or syntactic figures. In certain parts, the Slavonic version is closer to the Viennese Greek manuscript, but in the other ones, it is closer to the Jerusalem Ms. That's

14 Gospel of Nicodeme has been translated into Old Church Slavonic at least twice - from Latin and from Greek. The popularity of this text in the Slavonic environment is evidenced in the great number of extent manuscripts, see: de Santos Otero, Handschriftliche Überlieferung, ss. 61-98.

This translation is preserved in the Codex Suprasliensis and in the German's Miscellany, seе: Д. Иванова-Мирчева, Ж. Икономова, Хомилията на Епифаний за слизането в aдa, Sofia, 1975 . 
why it is not possible to choose only one of the Greek versions for the research, but it is necessary to reflect both of them.

Two different redactions can be found in the manuscripts - the first one preserves the text in the form of the presumed archetype of the translation (MSS D, P, U and T), while the second redaction (MSs V and B) is developed from the unpreserved hyparchetype I in which the text was slightly modified:

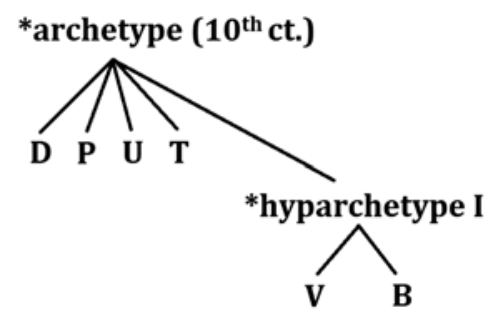

There is a number of similarities between the MSS V and B, but one of the most important modifications of the text was made due to the heretical elements present at the beginning of the first chapter. These elements are related to the question of the narration time: whether the apostles are talking to Christ (and asking him about his descent into Hades) before or after his resurrection:

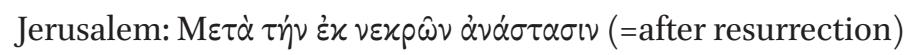

Casanatense: In illo tempore antequam pateretur dominus (=before the suffering)

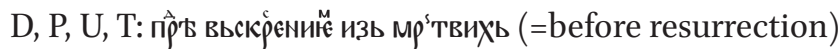

V, В: по въскерсенїи из мрьтвый (=after resurrection)

According to the Christian dogmatics, the apostles could meet Christ before his death or after his resurrection, but not in the meantime. From the other hand, following the Monophysite or Docetic heresy, they could meet him in that time, because the Christ's resurrection represents his return to the full divinity which is not bearable for human beings. Confusing statement in the Latin version and different variants in the Slavonic Mss lead us to conclusion that in the direct Greek unpreserved pattern of the Slavonic translation, the statement "before resurrection“ was placed, but later it was evaluated as something wrong, so it had to be corrected.

The Slavonic translation was made in Bulgaria in the 1oth century and most likely in a place connected with the Preslav Literary School. This could be evidenced by the lexical elements typical for this period, e.g. the multiple usage of 
ptc. оврадаванаға for the Greek $\chi \varepsilon \chi \alpha \rho \imath \tau \omega \mu \varepsilon \dot{\eta} \eta$ addressing to Virgin Mary instead of archaic влагодАтнаға, or the subst. вєрига for Greek $\alpha^{\prime} \lambda \nu \sigma \iota \zeta$ instead of archaic

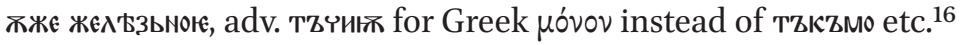

On the other hand, the text shows some archaic elements with known Preslav innovating equivalents. This could lead us to two possible conclusions. First, the translation was done early in the 1oth century in a time when the archaic elements had not been replaced yet by the Preslav innovations. Second, the translation could have been done some time during the 1oth century in one of the scriptoria applying specific rules on the usage of archaisms and preslavisms. However, as the exact role of the preslavisms and their function in the wider Slavonic context has not been satisfactorily stated yet, we keep the question of a more precise dating open. Either way from the linguistic, lexical and extra-linguistic perspective, the extant Slavonic manuscripts do not raise doubts that the translation was made in Bulgaria in the 1oth century.

As the translation is preserved in two manuscripts referring to the Serbian redaction of Church Slavonic and in four manuscripts referring to the Russian redaction, there is a question on the text spreading through the Slavic environment. We cannot exclude a possibility that the text was included in the large Bulgarian Imperial Library. This library was taken by the Byzantian emperor John I Tzimiskes in 970-972 and moved first to Constantinople and later to Kievan Rus' where it is supposed to be still held as a whole piece until the Mongol invasion. In that period it was probably as a whole piece destroyed..$^{17}$ As a lot of other texts, the apocrypha enjoyed quite a popularity in the Russian environment. We suppose that the text was transferred to Serbia from Russia as there were established strong cultural contacts between the Grand Duchy of Moscow, Second Bulgarian Empire and Serbia under the reign of the Nemanjic dynasty, ${ }^{18}$ nevertheless it cannot be exluded that the text arrived there directly from Bulgaria.

At the very end of this contribution, we would like to present our future plans with our research on the Slavonic version of the Questions of Bartholomew. The first step will be the evaluation of the Venetian Greek manuscript and

16 For more of this topic see the survey of preslavisms in Bart in: M. Chromá, "Преславизмы в апокрифических Вопросах апостола Варфоломея," Studia Ceranea, 4 (2014), pp. 27-34, or the contribution dedicated to analysis of the biblical quotations: M. Chromá, "Biblické citáty v apokryfních Otázkách Bartolomějových," Slavia, 85 (2016), pp. 287-302. А.А. Турилов, Межславянские культурные связи эпохи средневековья и источниковедение истории и культуры славян, Mоscow, 2012, p. 201. 
its comparison with the other Greek versions and with the Slavonic translation. As soon as this is completed, we plan to publish a monograph by 2019. The monograph will include a comprehensive study, critical edition of the Slavonic text including variant readings from all Slavonic manuscripts and also with the parallel Greek and Latin versions. Both Old Church Slavonic - Greek and Greek - Old Church Slavonic indices will also be included, so the lexical material of the apocryphon will be further usable for the comparison with other Old Church Slavonic texts translated from Greek. Publication of the monograph will be supported by the project GORAzD: Digital Portal of Old Church Slavonic, which is currently carried out in the Institute of Slavonic studies of the Czech Academy of Sciences. ${ }^{19}$

19 “GorAzD: Digital Portal of Old Church Slavonic," n.p. [cited 15 November 2016] Online: $<$ http://www.gorazd.org $>$. 